\title{
The genus Crispatotrochus Tenison-Woods, 1878 (Anthozoa Scleractinia) from the Mediterranean Pliocene
}

\author{
Valeriano Spadini \\ Via A. Toti 4, 52046 Lucignano, Arezzo, Italy; e-mail: spadiniv@inwind.it
}

\begin{abstract}
A undetermined species of Crispatotrochus Tenison-Woods, 1878 (Anthozoa Scleractinia) from the Early Pliocene of Monte Calcinaio, in Radicofani basin (Italy, Toscana, Siena,) is herein described. This genus is still recorded worldwide, but is unknown in the eastern Atlantic and Mediterranean Sea. This is the first report of this genus from the Mediterranean Pliocene.
\end{abstract}

KEY WORDS $\quad$ Early Pliocene; Tuscany, Monte Calcinaio; Scleractinian; Caryophyllidae; Crispatotrochus.

Received 17.09.2018; accepted 29.10.2018; printed 30.12.2018; published online 07.01.2019

\section{INTRODUCTION}

The Pliocene scleractinian corals from the Siena area (Central Italy) was described by Spadini (2015, 2016). Although most of this scleractinian fauna, which includes more than fifty species, is well known, a part of it is still waiting to be classified. In particular, the studied species is now assigned to the Crispatotrochus Tenison-Woods, 1878, a genus of solitary scleractinian Caryophyllidae Gray 1847 found only in the Pliocene outcrops of Monte Calcinaio (Siena).

The scleractinian fauna of Monte Calcinaio in the Radicofani basin is characterized by numerous species belonging to genera reported for the first time from the Mediterranean Pliocene (Bathelia Moseley, 1881; Coenosmilia Pourtalès, 1874; Pourtalosmilia Duncan, 1884; Tethocyathus Kühn, 1933; Monomyces Ehrenberg, 1834) or others considered doubtful until now (Coenocyathus Milne Edwards et Haime, 1848; Stenocyathus Pourtalès, 1874) (Spadini, 2015, 2016). These genera currently include species that live on hard or detrital substrates from infralittoral to circalittoral and in some cases bathyal environments.

Conversely, in the outcrops of Monte Calcinaio, species associated with soft clay sediments that compose the group of dominant corals in other Sienese deposits (and more generally in the Mediterranean Pliocene) are lacking or very rare. These species belong to the genera/subgenera Caryophyllia (Ceratocyathus) Seguenza, 1864, Ceratotrochus Milne Edwards et Haime, 1848, Flabellum Lesson, 1831 and Balanophyllia (Eupsammia) Milne Edwards et Haime, 1848 (Spadini, 2015).

This short note analyses specimens of a species associated with hard substrates, which does not appear in the Pliocene or Recent fauna of the Mediterranean Sea, but can be compared with certain species now living in the Atlantic and Indo-Pacific Oceans (Kitahara \& Cairns, 2008). The fundamental morphological characters of these specimens, broad base, columella with an irregular group of elements, and no pali and endotheca, suggest that this species belongs to the genus Crispatotrochus of the family Caryophyllidae. 
This is the first report of this genus from the Mediterranean Pliocene.

\section{MATERIAL AND METHODS}

The material studied in the present report was found at a site on Monte Calcinaio (altitude 732

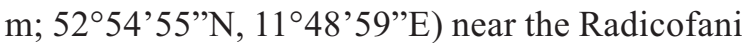
district in the Radicofani basin (Tuscany, Italy) (Figs. 1, 2). Pliocene sedimentation in this area started at the beginning of the Pliocene (Zanclean) and lasted until the Early Piacentian. In the central part of the sedimentation basin, it developed mostly in a neritic environment and sediments, for the most part consist of deep-sea clays with sandy-conglomeratic intercalations, attributable to the G. margaritae Bolli et Bermudez, 1965 biozone (Liotta, 1996; Pascucci et al., 2006, Spadini, 2016).

ABBREVATION AND ACRONYMS. The following abbreviations are used in the text: $\mathrm{D}=$ maximum calicular diameter; $\mathrm{d}=$ minimum calicular diameter; $\mathrm{H}=$ maximum height; $\mathrm{Sx}=$ septa of cycle x (S1, S2, etc.); MUSNAF = Museo di Storia Naturale dell'Accademia dei Fisiocritici, Siena.

\section{RESULTS}

\section{Systematics}

Classis ANTHOZOA Ehrenberg, 1834

Subclassis HEXACORALLIA Haeckel, 1866

Ordo SCLERACTINIA Bourne, 1900

Familia CARYOPHYLLIDAE Gray, 1847

Genus Crispatotrochus Tenison-Woods, 1878

Type Species. Crispatotrochus inortatus Tenison-Woods, 1878, by monotypy.

Diagnosis. Corallum solitary, ceratoid to turbinate, usually attached. Septal symmetry hexameral or decameral. Septotheca costate or bearing transverse ridges. Pali absent. Columella fascicular composed of twisted elements (Kitahara \& Cairns, 2008).

Distribution. The genus Crispatotrochus is recorded worldwide with numerous Recent species, but is unknown in the eastern Atlantic and Mediterranean Sea (Kitahara \& Cairns, 2008). It occurs at depths from 82 to $2,505 \mathrm{~m}$.

Stratigraphic Distribution. Crispatotrochus is known from the Paleogene to Recent with six fossil species (Stolarski, 1996).

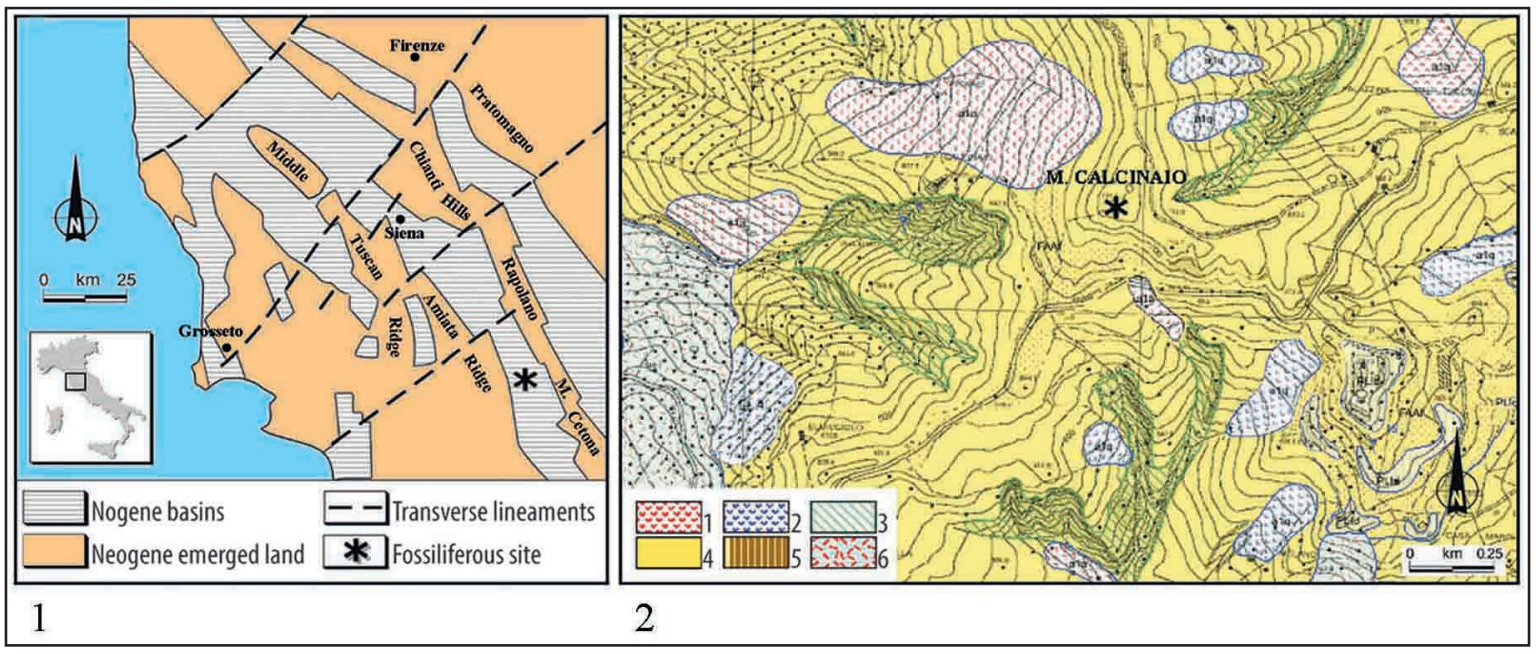

Figures 1, 2. Location of the studied outcrop. Fig. 1. Simplified structural setting of the studied area (Tuscany, Italy) showing the Monte Calcinaio fossiliferous site in the Radicofani basin (asterisk). Modified from Spadini \& Manganelli, 2016. Fig. 2. Simplified geological sketch of the area of Monte Calcinaio (asterisk). Modified from the Carta Tecnica Regionale 321060 (downloaded from http://www502.regione.toscana.it/geoscopio/cartoteca.html). 1: active landslide; 2: dormant landslide; 3: badlands; 4: Zanclean-Piacentian fossiliferous clays and silty clays; 5: Zanclean-Piacentian polygenic breccias; 6: Holocenic slope deposits. 
REMARKS. Crispatotrochus (= Cyathoceras Moseley, 1881; type species Cyathoceras cornu Moseley, 1881) is closely related to Caryophyllia, but is devoid of pali. It differs from Labyrinthocyathus Cairns, 1979 in columellar characters. Psammocyathus Chevalier 1963 (type species Psammocyathus pirenaïcum Chevalier, 1963) described as a subgenus of Cyathoceras, has a columella consisting of anastomosing paliform lobes and is very similar to Crispatotrochus, but Cauhzac \& Chaix (1996) consider Psammocyathus pirenaïcum to be a synonym of the colonial oculinid Diplohelia conferta (Milne-Edwards et Haime, 1850).

Vaughan \& Wells (1843) and Wells (1956) consider Crispatotrochus synonymous with Ceratotrochus Milne Edwards et Haime, 1848. Chevalier (1987) considered it a subgenus of Edwardsotrochus Chevalier, 1961, different from Cyathoceras, but a senior synonym of Labyrinthocyathus.

Conversely, Cairns (1991) considers Cyathoceras synonymous with Crispatotrochus, which has priority (Cairns, 1991), and Labyrinthocyathus as a separate genus.

In this short note, in agreement with Cairns (1991), it is sustained that Crispatotrochus (=Cyathoceras) differs from Labyrinthocyathus in columellar character, while Psammocyathus remains of uncertain generic status.

The genus Crispatotrochus is recorded worldwide with about 13 valid Recent species (Kitahara $\&$ Cairns, 2008) and is known from the Paleogene (Stolarski, 1996) with six fossil species. Two of them, C. tortonensis (Chevalier, 1961) from the Tortonian of Moncucco (Italy) and C. demarcqi Chevalier, 1963, from the Miocene of France, have four septal cycles. Crispatotrochus antarcticus Stolarski, 1996, from the Antarctic Paleogene has four cycles and some fifth-cycle septa. Crispatotrochus periallus Squires, 1962, from the Oligocene of New Zealand and C. rubescens (Squires, 1958) from the Pliocene of New Zealand have five cycles of septa. Finally, C. galloprovincialis Chevalier et Demarcq, 1964, from the Miocene of France has decameral symmetry.

The species assigned to Crispatotrochus are characterized by a columella with a variable number of twisted elements. However, some species classified in this genus have a columella composed of variably fused ribbons and small buds. Among living species, $C$. irregularis from the Antarctic has a columella composed of closely united, poorly defined, twisted ribbons and C. septumdentatus $\mathrm{Ki}$ tahara et Cairns, 2008, from New Caledonia has a columella composed of closely grouped ribbons, fused into a solid mass (Kitahara \& Cairns, 2008). Among fossil species, C. antarcticus Stolarski, 1996, shows fused columellar elements similar to the columella of species of the genus Labirintocyathus (Stolarski, 1996). Even C. demarcqi (Chevalier et Demarcq, 1964) and C. galloprovincialis (Chevalier et Demarcq, 1964) from the Miocene of France have a columella with vertically arranged lobes.

Therefore, given the columellar variability in Crispatotrochus species, it is suggested that the Monte Calcinaio specimens can be included in this genus.

\section{Crispatotrochus sp. (Figs. 3-6)}

Examined Material. Monte Calcinaio (Siena, Italy), material collected by the author in the years



Figure 3. Calice of Crispatotrochus sp. from Monte Calcinaio (Siena, Italy). For explanation of the terms used in this figure, see Material and Methods. 


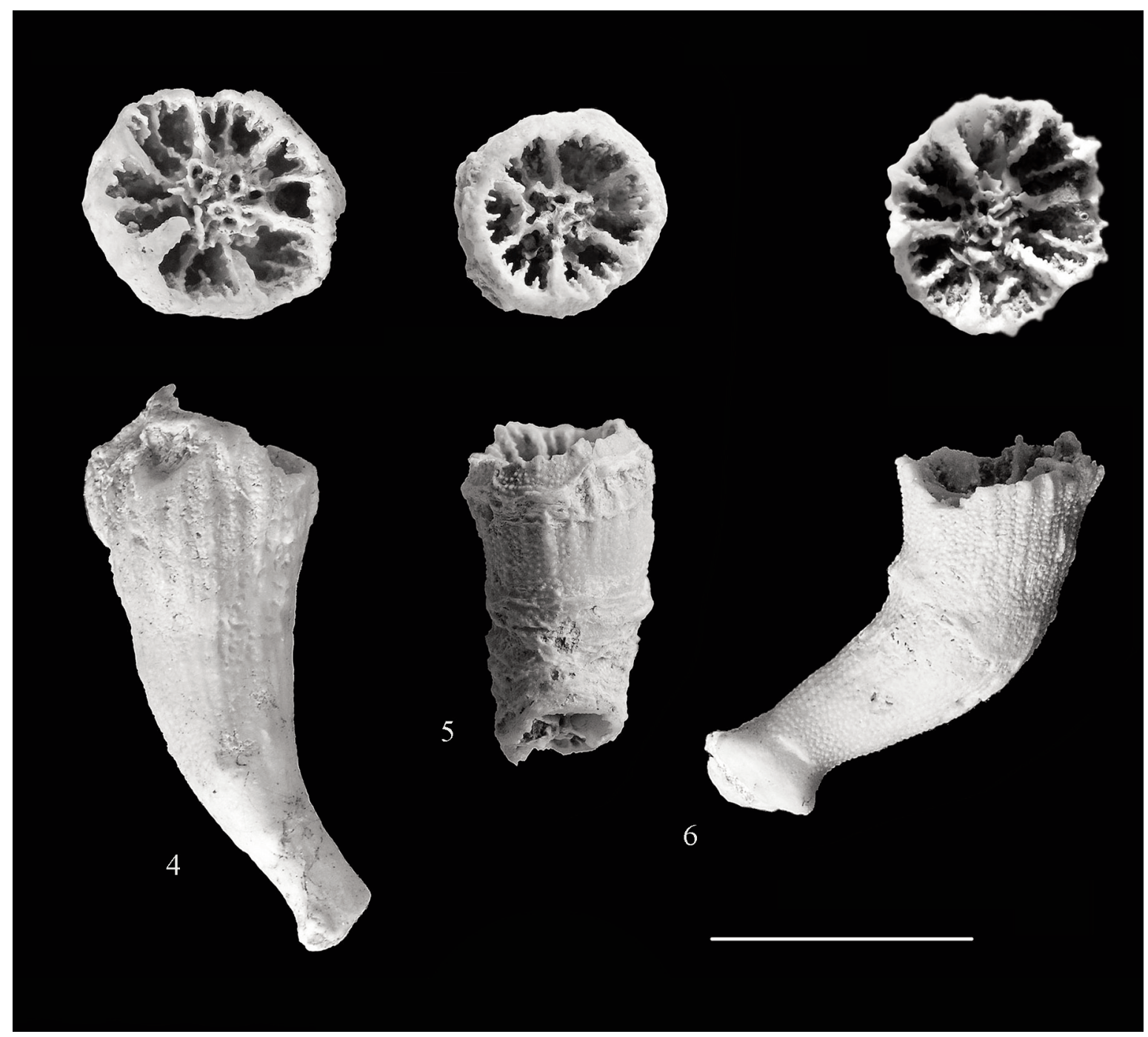

Figures 4-6. Crispatotrochus sp., Zanclean of Monte Calcinaio (Siena, Italy). Scale bar $=5 \mathrm{~mm}$.

2010-1015. Two complete and two incomplete specimens and some fragments. The materials are kept in the Museo di Storia Naturale dell'Accademia dei Fisiocritici di Siena, Geo-Paleontological Collections. Dimensions: specimen 1: H: 12.9, D: 4.3, d: 3.6, number of septa: 40; specimen 2: H: 9.8 , D: 4.2 , d: 4 , number of septa: 40 ; specimen $3: \mathrm{H}$ : 10.9, D: 4.7, d: 4.6, number of septa: 28; specimen 4: H: 7.3, D: 5.6, d: 5.3, number of septa: 24 .

DESCRIPTION. Corallum ceratoid, elongated, curved, slightly flared distally. Encrusting base, slightly enlarged. Theca costate, consisting of broad, slightly convex costae, separated by very fine shallow intercostal grooves and uniformly covered in small granules. Circular or slightly elliptical calice with partially preserved edge. Four incomplete cycles of septa, arranged in six systems, up to a maximum of 40 septa in large specimens. S1 very compact, slightly exserted, with straight axial edges that reach and merge with the columella. S2 are less exserted, also with straight axial edges that merge with the columella deeper than S1. S3 are wide around a quarter or half of calice diameter and S4 are rudimentary and very fine. Sometimes S4 bear short upward-curving lobes. The ornamentation of the inner face of the septa consists of granules of unknown form and constitution. 
Fossa shallow with circular or elliptical columella, composed of fine grouped ribbons, more or less fused together by non twisted, vertical, or more rarely oblique lobes and lamellae, irregularly disposed on the columella (Fig. 3).

Remarks. Crispatotrochus sp. of Monte Calcinaio is distinguished from its congeners, which have four incomplete cycles of hexamerally arranged septa, by thick S1 and less thick S2.

Two of the incomplete specimens examined lack a base, while two other specimens are attached via thick pedicels and encrusting bases (Figs. 5, 6).

In specimens with 40 septa (Fig. 3), the columella consists of interconnected lamellae, like in Psammocyathus, but one of these specimens shows variably evident irregular buds or small lobes arranged vertically or obliquely.

The presence of an undescribed species of the genus Crispatotrochus from the Pliocene of Monte Calcinaio, with other undetermined species belonging to genera hitherto unknown from the Mediterranean Pliocene (Spadini, 2015, 2016), is of considerable importance for reconstructing events in the early Pliocene. It is further evidence that the Pliocene history of scleractinian azooxanthellate corals of the Mediterranean Sea is still poorly understood.

\section{ACKNOWLEDGEMENTS}

I am grateful to Giuseppe Manganelli (Università di Siena, Italy) for the help with bibliographical research, to Francesco Pizzolato (Arezzo, Italy) for the help in the search for material and to Helen Ampt (Siena, Italy) for revising the English.

\section{REFERENCES}

Cairns S.D., 1991. A revision of the ahermatypic Scleractinia of the Galapagos and Cocos Islands. Smithsonian Contributions to Zoology, 504: 1-44. DOI: 0.5479/si.00810282.504

Cauhzac B. \& Chaix C., 1996. Structural and faunal evolution of Chattian-Miocene reefs and corals in Western France and Northeastern Atlantic Ocean. In: Franseen E., Esteban M., Ward W. \& Rouchy J.M., (Eds.), Models for Carbonate Stratigraphy from Miocene Reef Complexes of the Mediterranean Re- gions, Society of Economic Paleontologists and Mineralogists, Tulsa, Concepts in Sedimentology and $\mathrm{Pa}-$ leontology, 5: 105-127.

Chevalier J.P., 1963. Les madréporaires de l'Aquitanien inférieur de Peyrère près de Peyrehorade (Landes). Les Annales de l'Universite et de l'ARERS, 2: 4760.

Chevalier J.P. \& Beauvais L., 1987. Ordre des Scléractiniaires. In: Grassé P.P. (Ed.), Traité de Zoologie, Tome III, fasc. 3., Paris, Masson, pp. 679-764.

Chevalier J.P. \& Demarcq G., 1964. Les madréporaires miocènes de la vallée du Rhône. Travaux du Laboratoire de Géologie de la Faculté des Sciences de Lyon, 11: 7-48.

Kitahara M.V. \& Cairns S.D., 2008. New records of the genus Crispatotrochus (Scleractinia; Caryophylliidae) from New Caledonia, with description of a new species. Zootaxa, 1940: 59-68.

Liotta D., 1996. Analisi del settore centro-meridionale del bacino pliocenico da Radicofani (Toscana Meridionale). Bollettino della Società Geologica italiana, 115: 115-143.

Milne Edwards H. \& Haime J., 1850. Recherces sur les polypiers. Cinquieme mémoire: monographie des oculinides. Annales des sciences naturelles, Zoologie, 13: 63-110.

Moseley H.N., 1881. Report on certain Hydroid, Alcyonarian, and Madreporarian corals procured during the Voyage of H.M.S. Challenger, in the years 18731876. Report on the Scientific Results of the Voyage of H.M.S. Challenger during the Years 1873-76. Zoology, 2: 1-248.

Pascucci V., Costantini A., Martini I.P. \& Dringoli R., 2006. Tectono-sedimentary analysis of a complex, extensional, Neogene basin formed on thrust-faulted, Northern Apennines hinterland: Radicofani Basin, Italy. Sedimentary Geology, 183: 71-97. DOI: 10. 1016/j.sedgeo.2005.09.009

Spadini V., 2015. Sclerattiniari del Pliocene senese. Accademia delle Scienze di Siena detta dei Fisiocritici "Memorie", 13: 1-160.

Spadini V., 2016. First occurrence of the genus Bathelia (Anthozoa, Scleractinia) from the Mediterranean Pliocene. Bollettino della Società Paleontologica Italiana, 55: 219-222.

Spadini V. \& Manganelli G., 2016. A megachasmid shark tooth (Chondrichthyes, Lamniformes) from the Zanclean (early Pliocene) of San Quirico d'Orcia, central Italy. Bollettino della Società Paleontologica Italiana, 2015, 54: 67-70.

Stolarski J., 1996. Paleogene corals from Seymour Island, Antarctic Peninsula. In: A. Gaidzicki (Ed.), Palaeontological Results of the Polish Antarctic Expeditions. Part 11. Palaeontologia Polonica, 55: 5163. 
Vaughan T.W. \& Wells J.W., 1943. Revision of the suborders, families and genera of the Scleractinia. Geological Society American, Special paper, 44: $1-363$.
Wells J.W., 1956. Scleractinia. In: Moore R.C. (Ed.), Treatise on Invertebrate Paleontology, Part F: Coelenterata. University of Kansas Press, Lawrence, pp. F328-F444. 